\title{
Analisis Bibliometrik Terhadap Kemampuan Komunikasi Matematis Berdasarkan Perbedaan Gender berbasis VOSViewer
}

\author{
Dinda Haniyah ${ }^{1}$, Joko Soebagyo ${ }^{2}$ \\ 1Pendidikan Matematika, Universitas Muhammadiyah Prof. Dr. Hamka, Jakarta, Indonesia; \\ *haniyah.dinda99@gmail.com \\ 2Pendidikan Matematika, Universitas Muhammadiyah Prof. Dr. Hamka, Jakarta, Indonesia;
}

\begin{abstract}
Abstrak. Dalam kemampuan komunikasi matematis sangat penting untuk dimiliki oleh siswa. Tujuan penelitian ini adalah untuk mengkaji penelitian mengenai kemampuan komunikasi matematis siswa dalam pembelajaran matematika berdasarkan perbedaan gender selama enam tahun belakangkan ini. Teknik pengumpulan data dengan cara penelusuran menggunakan Google Scholar dengan kata kunci mathematical, communication, gender, dalam kurun waktu 2015-2021. Analisis data menggunakan software VOSviewer dengan data yang didapatkan dari software Publish or Perish. Kesimpulan dari penelitian ini adalah ditemukan 34 kata kunci yang terbagi dalam 9 cluster. Pada jejaring kepenulisan dari 1676 penulis dengan minimal jumlah 3 dokumen yang dipulikasikan, terdapat 33 penulis yang memenuhi batas minimum jejaring kepenulisan. Publikasi terbanyak terjadi pada tahun 2020 sebanyak 306 dalam Google Scholar.
\end{abstract}

Kata Kunci: Kemampuan komunikasi matematis, perbedaan gender, analisis bibliometrik, VOSViewer.

\begin{abstract}
In mathematical communication skills are very important for students. The purpose of this study was to examine research on students' mathematical communication skills in learning mathematics based on gender differences for the past six years. Data collection techniques by searching using Google Scholar with the keywords mathematical, communication, gender, in the period 2015-2021. Data analysis using VOSviewer with data obtained from Publish or Perish software. The conclusion of this research is that 34 keywords are found which are divided into 9 clusters. In the authorship network of 1676 authors with a minimum number of 3 published documents, there are 33 authors who meet the minimum authorship network limit. The most publications occurred in 2020 as many as 306 in Google Scholar.
\end{abstract}

Keywords: Bibliometric analysis, mathematical communication skills, gender differences, VOSViewer.

\section{Pendahuluan}

Manusia merupakan mahluk sosial yang hidupnya tidak lepas dengan orang lain. Dalam hal ini manusia harus mempunyai kemampuan berkomunikasi 
jika ingin berinteraksi dan bersosialisasi. Tetapi hal yang dapat diajarkan pada siswa adalah mereka mampu untuk menjelaskan fakta dan dapat membuat kesimpulan dari pemikiran dari yang tertulis maupun tidak tertulis. Permasalahan keterampilan yang dapat dikuasai yaitu keterampilan bertindak dan berpikir: produktif, kritis, kreatif, kolaboratif, komunikatif, dan mandiri dalam pendekatan yang sesuai dengan apa yang telah dipelajari dari sekolah secara mandiri (Nugraha \& Pujiastuti, 2019).

Dalam pembelajaran matematika identik dengan perhitungan maupun rumus, jadi banyak tanggapan bahwa keterampilan komunikasi matematis tidak dapat dibangun pada pembelajaran matematika. Pada keterampilan komunikasi keterkaitannya sangat penting dalam pembelajaran matematika (Babys, 2020). Dalam proses pengajaran terdapat masalah pada siswa khususnya dalam pembelajaran matematika yaitu, kurang mandiri dalam belajar, kebiasaan yang buruk dalam belajar seperti cepat bosan, menyontek, mengantuk maupun belajar hanya saat akan ada ujian, yang terakhir adalah mencari dan menerima jawaban soal ujian (Maijala et al., 2004).

Komunikasi adalah hal yang sangat penting dalam seluruh aspek kehidupan terutama dunia pendidikan, sehingga aspek kemampuan komunikasi matematis adalah contoh khusus yang harus diperhatikan. Pada tingkatan SMP atau SMA, kemampuan komunikasi matematis belum berkembang (Suswigi et al., 2019). Kemampuan komunikasi matematis siswa berada pada tingkatan bawah khususnya aspek dalam kemampuan ide-ide komunikasi matematis. Permasalahan aspek yang menyangkut nilai mengenai kemampuan komunikasi tentang prosedur, fakta, pemahaman konsep, dan penerapan pengetahuan (Taqwa \& Sutrisno, 2019).

Kemampuan komunikasi matematika adalah cara siswa dalam menyelesaikan dan menafsirkan gambar, rumus, tabel, demontrasi, ataupun diagram. Dalam hal tersebut komunikasi matematis hal yang penting karena siswa dapat sharing informasi, bertukar pemikiran, pengetahuan dan pemahaman pembelajaran matematika. Faktor yang dapat mempengaruhi kemampuan komunikasi matematis terhadap matematika itu sendiri adalah faktor gender atau jenis kelamin. Permasalahan jenis kelamin siswa atau faktor gender terdapat perbedaan dari kemampuan psikologi belajar siswa. Selanjutnya banyak siswa laki-laki dan perempuan memiliki perbedaan yang jauh dalam belajar matematika (Babys, 2020). 
Permasalahan tersebut berkaitan dengan perbedaan gender. Perbedaan gender dipengaruhi oleh adanya perbedaan dalam otak anak perempuan dan laki-laki yang diketahui bahwa anak perempuan lebih unggul daripada anak laki-laki (Suswigi et al., 2019). Perbedaan gender juga berpengaruh prestasi dalam belajar matematika adalah bagaimana kodisi keadaan, keterampilan, serta menyelesaikan tugas yang diberikan oleh guru. Maka dari itu perbedaan gender dalam pembelajaran matematika adalah bagaimana kemampuan komunikasi matematis mampu berjalan dengan baik.

Kemampuan komunikasi matematis dalam perbedaan gender memiliki peran yang positif, karena jika perbedaan gender pada siswa dalam kemampuan komunikasi matematis yang tinggi maka biasanya siswa tersebut dapat mengatasi berbagai macam permasalahan, dan dapat mencapai hasil serta tujuan pembelajaran matematika. Karena perbedaan gender pada siswa merupakan hasil dari proses psikologi individu dalam pembelajaran sehingga siswa dapat menghasilkan hasil belajar yang tercapai dengan baik, hal ini didasarkan pada pernyataan Suswigi dkk diatas.

Salah satu faktor yang dapat mempengaruhi komunikasi matematis seseorang adalah gender atau jenis kelamin (Taqwa \& Sutrisno, 2019). Umumnya perempuan memiliki komunikasi matematis yang lebih tinggi dalam mengendalikan perannya daripada komunikasi matematis laki - laki. Hal ini juga selaras dengan pernyataan (Suswigi et al., 2019) bahwa komunikasi matematis yang dimiliki perempuan lebih tinggi daripada komunikasi matematis laki - laki, hal ini disebabkan karena perempuan bisa menyapu bersih kegiatannya menjadi wanita karir dan ibu rumah tangga sedangkan laki - laki hanya dapat bekerja saja. Namun selain itu ada penelitian yang mengungkapkan bahwa laki - laki memiliki komunikasi matematis yang tinggi dibanding perempuan seperti pada Zhixia dalam (Ratna et al., 2019). berpendapat bahwa di Amerika Serikat dan negara lain juga berpendapat bahwa kemampuan matematika laki-laki lebih meningkat daripada perempuan. Lalu siswa laki - laki mempunyai nilai tes matematika yang lebih tinggi dibanding siswa perempuan (Ratna et al., 2019).

Tujuan dari pembelajaran matematika yaitu kemampuan komunikasi matematis yang dapat dipelajari untuk semua gender. Dalam proses pada kurikulum terdapat bagaimana pola dan langkah-langkah yang digunakan siswa dalam mengkomunikasikan pembelajaran matematika pada perbedaan gender. Dengan demikian perbedaan gender dapat mendorong siswa untuk menggali kemampuan komunikasi matematis. Memungkinkan bahwa

Copyright (C) 2021

Buana Matematika :

Jurnal Ilmiah Matematika dan Pendidikan Matematika 
kemampuan komunikasi matematis memerlukan tingkat daya berpikir yang tinggi oleh siswa, akan tetapi dapat dipelajari untuk semua gender yang berbeda.

Berdasarkan uraian di atas peneliti ingin menganalisis bagaimanakah pengaruh gender atau jenis kelamin terhadap kemampuan komunikasi matematis siswa dengan menggunakan VOSViewer.

\section{Metode}

Penelitian ini menggunakan metode analisis bibliometrik. Analisis bibliometrik adalah metode kuantitatif yang digunakan untuk menganalisis data bibliografi yang berada pada artikel atau jurnal. Analisis ini dapat membantu peneliti dalam meninjau isi bibliografi, analisis sitasi dari setiap artikel yang dimuat dalam jurnal internasional mengenai kemampuan komunikasi matematis berdasarkan gender dari tahun 2015-2021 pada Google Scholar dengan menggunakan software Publish or Perish.

\section{Subjek Penelitian}

Penelitian ini berdasarkan artikel internasional tentang kemampuan pemecahan masalah berdasarkan gender dari tahun 2015-2021 pada Google Scholar. Untuk lebih jelasnya penjelasan mengenai data yang diambil dari software Publish or Perish dengan menggunakan Google Scholar dapat dilihat pada tabel berikut.

Tabel 1. Subjek Penelitian

\begin{tabular}{ll}
\hline Result & Explanation \\
\hline Query & $\begin{array}{l}\text { Bibliometric analysis of } \\
\text { Communication Skills in Mathematics Learning } \\
\text { Based on Gender Differences using VOSViewer }\end{array}$ \\
\hline Publication Years & $2015-2021$ \\
\hline Citation Years & $6(2015-2021)$ \\
\hline Papers & 997 \\
\hline Citations & 3808 \\
\hline
\end{tabular}

Copyright (C) 2021

Buana Matematika :

Jurnal Ilmiah Matematika dan Pendidikan Matematika 


\begin{tabular}{ll}
\hline Cites/year & 634.67 \\
\hline Cites/paper & 3.82 \\
\hline Authors/paper & 2.15 \\
\hline h-index & 27 \\
\hline g-index & 45 \\
\hline hI-norm & 23 \\
\hline hI-annual & 3.83 \\
\hline hA-index & 12 \\
\hline
\end{tabular}

Berdasarkan tabel 1 diatas, publikasi artikel internasional tentang kemampuan pemecahan masalah berdasarkan gender dari tahun 2015-2021 pada Google Scholar dengan menggunakan software Publish or Perish didapatkan sebanyak 997 papers, 3808 kali sitasi, 634.67 kali sitasi per tahun, 3.82 kali sitasi per paper, 2.15 penulis per paper, dengan $20 \mathrm{~h}$-index dan $45 \mathrm{~g}$ index, 23 hI-norm, 3.83 hI-annual, dan 12 hA-index.

\section{Teknik Pengumpulan Data}

Pengumpulan data pada penelitian ini dilakukan dengan menggunakan software Publish or Perish dalam Google Scholar dengan kata kunci "Mathematical Communication Skills in Mathematics Learning Based on Gender Differences". Selanjutnya data disimpan dalam beberapa format yang diperlukan. Data yang telah disimpan kemudian diolah dengan menggunakan software VOSviewer.

\section{Teknik Analisis Data}

Teknik analisis data yang digunakan dalam penelitian ini adalah analisis bibliometrik. Menurut (Royani \& Idhani, 2018) bibliometric merupakan cara sistematik yang digunakan dalam menganalisis jurnal-jurnal ilmiah yang sudah terbit maupun digital. Analisis Bibliometrik ini juga merupakan kajian cukup bisa dibilang tua dalam ilmu perpustakaan dan merupakan kajian kuantitatif.

Copyright (C) 2021

Buana Matematika :

Jurnal Ilmiah Matematika dan Pendidikan Matematika 
Terdapat dua variabel dalam penelitian ini, yaitu variabel bebas dan variabel terikat. Gender merupakan variabel bebas dan kemampuan komunikasi matematis merupakan variabel terikat.

Tahapan-tahapan yang dilakukan dalam menganalisis data pada penelitian ini adalah dengan cara melakukan pengumpulan data menggunakan software Publish or Perish dalam Google Scholar dengan kata kunci "Bibliometric Analiysis of Mathematical Communication Skills in Mathematics Learning Based on Gender Differences using VOSViewer". Selanjutnya data disimpan dalam beberapa format yang diperlukan. Data yang telah disimpan kemudian diolah dengan menggunakan software VOSviewer.

Metode menggambarkan langkah-langkah yang dilakukan selama penelitian. Pada bagian ini, tidak dibenarkan untuk menuliskan definisi dari istilah yang sudah umum diketahui (Contoh: Valid, Instrumen, Sampel, dsb). Perlu diperhatikan bahwa untuk artikel hasil penelitian maka metode penelitian harus dikemukakan dengan jelas meliputi proses dan rinciannya. Metode penelitian memuat tempat, subjek penelitian, deskripsi cara memperoleh data yang disertai dengan penjelasan serta metode yang digunakan dalam menganalisis data.

Artikel hasil kajian kepustakaan memiliki ketentuan pada perumusan masalah harus muncul secara eksplisit dan metode/cara mengkajinya harus dituliskan dibagian ini. Urutan yang dipaparkan pada bagian metode, harus sesuai dengan urutan pada bagian hasil penelitian.

\section{Hasil dan Pembahasan}

\section{A. Perkembangan Publikasi Internasional}

Berdasarkan hasil dari jumlah publikasi artikel internasional pada tabel 2 mengenai kemampuan komunikasi matematis dalam pembelajaran matematika berdasarkan perbedaan gender dari tahun 2015-2021 didapatkan 997 total publikasi yang dimuat pada Google Scholar. Distribusi artikel berdasarkan tabel 2 diawali dari tahun 2015-2021. Terdapat 65 (7\%) publikasi pada tahun 2015, 104 (10\%) publikasi pada tahun 2016, 151 (15\%) pada tahun 2017, 153 (15\%) pada tahun 2018, 189 (19\%) pada tahun 2019, 306 (31\%) pada tahun 2020, dan 29 (3\%) pada tahun 2021. Dengan demikian artikel yang paling banyak dipublikasikan dalam Google Scholar mengenai kemampuan pemecahan masalah matematis berdasarkan perbedaan gender adalah tahun 2020 dengan total publikasi 306.

Copyright $@ 2021$

Buana Matematika :

Jurnal Ilmiah Matematika dan Pendidikan Matematika 
Tabel 2. Perkembangan Publikasi

\begin{tabular}{c|c|c}
\hline Tahun & Jumlah Publikasi & Presentase (\%) \\
\hline $\mathbf{2 0 1 5}$ & 65 & 7 \\
\hline $\mathbf{2 0 1 6}$ & 104 & 10 \\
\hline $\mathbf{2 0 1 7}$ & 151 & 15 \\
\hline $\mathbf{2 0 1 8}$ & 153 & 15 \\
\hline $\mathbf{2 0 1 9}$ & 189 & 19 \\
\hline $\mathbf{2 0 2 0}$ & 306 & 31 \\
\hline $\mathbf{2 0 2 1}$ & 29 & 3 \\
\hline Total & $\mathbf{9 9 7}$ & $\mathbf{1 0 0}$ \\
\hline
\end{tabular}

Grafik 3. Perkembangan Publikasi

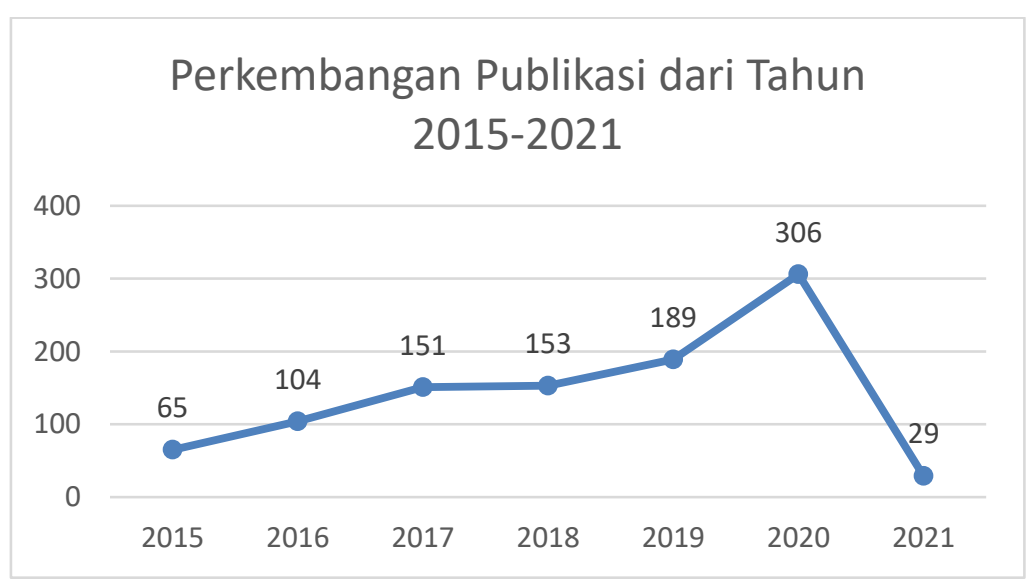

\section{B. Peta Perkembangan Publikasi Dilihat Dari Kata Kunci}

Berdasarkan data pada gambar 4, yang telah diperoleh dari Publish or Perish dan diolah menggunakan VOSviewer, dengan jumlah kemunculan minimal 4 dari 184 kata kunci, terdapat 34 kata kunci yang memenuhi ambang batas, dengan penjelasan sebagai berikut. 


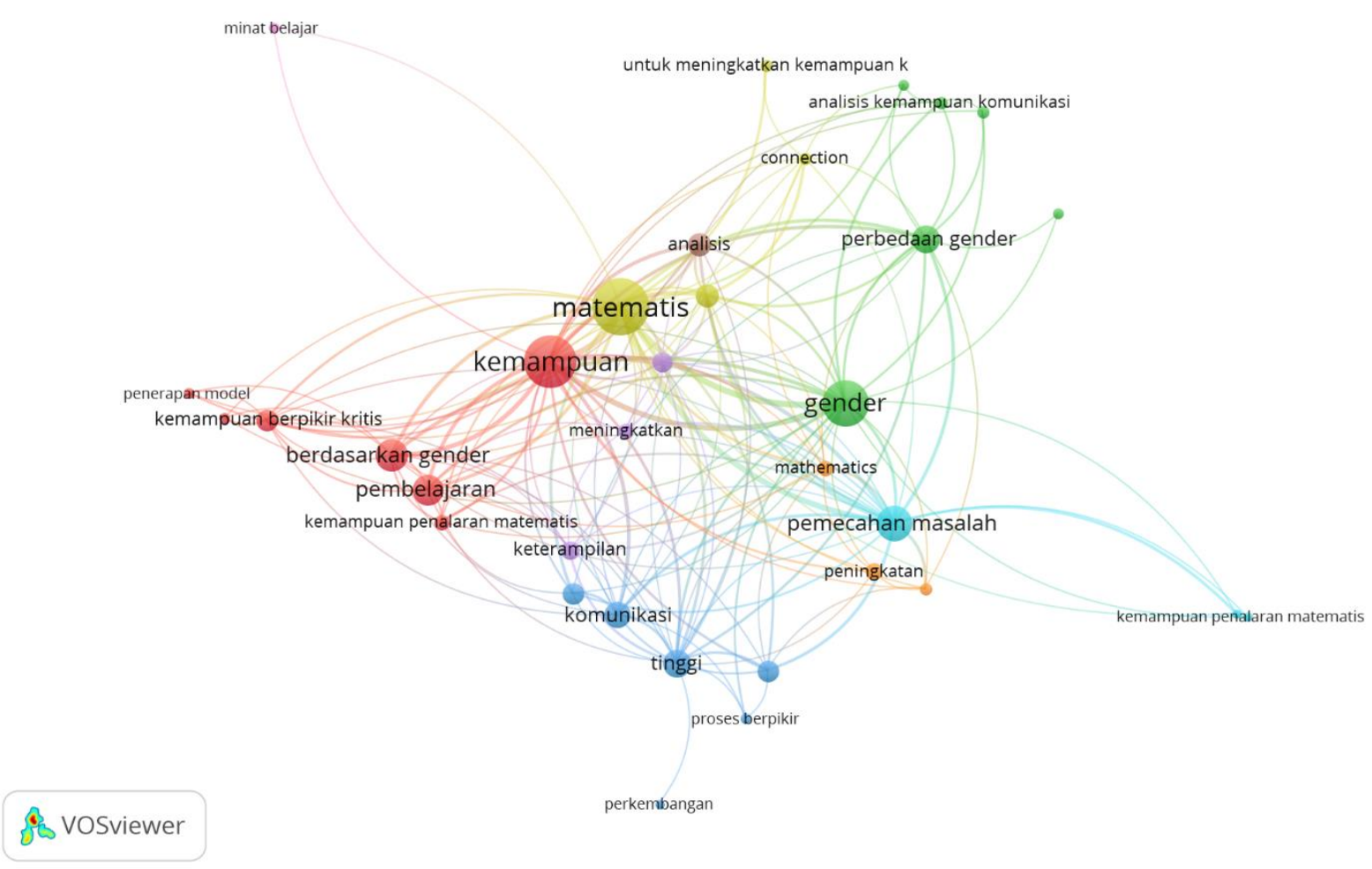

Sumber : Hasil Visualisasi Menggunakan VOSViewer

Gambar 4. Hasil Network Visualization

Dari 34 kata kunci yang dihasilkan pada gambar diatas, terdapat 9 Cluster dalam visualisasi tersebut. Yaitu:

Tabel 5. Hasil Clusters

\begin{tabular}{|l|l|}
\hline Clusters & Item \\
\hline Cluster 1 & $\begin{array}{l}\text { Berdasarkan gender, kemampuan, } \\
\text { kemampuan berpikir kritis, kemampuan } \\
\text { berpikir kritis matematis, kemamouan } \\
\text { penalaran matematis, pembelajaran. }\end{array}$ \\
\hline Cluster 2 & $\begin{array}{l}\text { Analisis kemampuan komunikasi matematis } \\
\text { dalam pemecahan masalah matematika, } \\
\text { analisis kemampuan komunikasi matematis }\end{array}$ \\
\hline
\end{tabular}

Copyright (C) 2021

Buana Matematika :

Jurnal Ilmiah Matematika dan Pendidikan Matematika 


\begin{tabular}{|l|l|}
\hline & $\begin{array}{l}\text { siswa berdasarkan perbedaan gender, gender, } \\
\text { gender difference. }\end{array}$ \\
\hline Cluster 3 & $\begin{array}{l}\text { Kemampuan matematika, komunikasi, } \\
\text { perkembangan, proses berpikir, SMA, SMP, } \\
\text { SD, tinggi }\end{array}$ \\
\hline Cluster 4 & Communication, connection, matematis. \\
\hline Cluster 5 & $\begin{array}{l}\text { Keterampilan, meningkatkan, pemecahan } \\
\text { masalah matematis. }\end{array}$ \\
\hline Cluster 6 & $\begin{array}{l}\text { Kemampuan penalaran, pemecahan masalah, } \\
\text { penalaran dan komunikasi }\end{array}$ \\
\hline Cluster 7 & Komunikasi, mathematics, peningkatan. \\
\hline Cluster 8 & Analisis. \\
\hline Cluster 9 & Minat belajar. \\
\hline
\end{tabular}

\section{Peta Perkembangan Publikasi Berdasarkan Penulis}

Berdasarkan hasil penelitian pada gambar 6, peneliti memperoleh total 1676 penulis karya ilmiah yang terbagi ke dalam 997 hasil penelusuran Google Scholar. Dengan jumlah minimal 3 dokumen yang dipublikasikan penulis, terdapat 33 penulis yang memenuhi ambang batas jejaring kepenulisan seperti pada gambar berikut ini. 


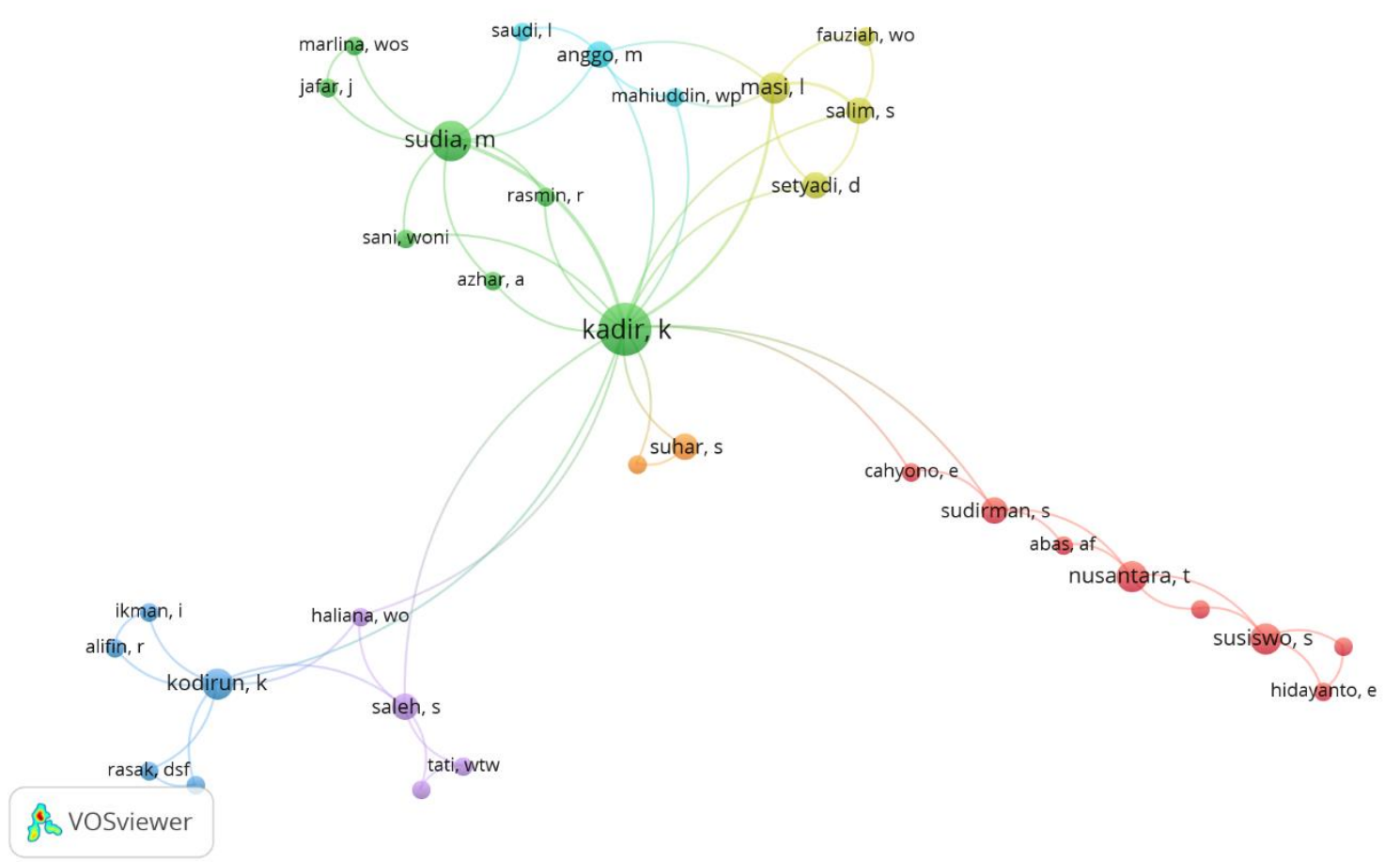

Sumber : Hasil Visualisasi Menggunakan VOSViewer

Gambar 6. Hasil Analisis Kepengarangan

Dari gambar 6, dapat dilihat bahwa Kadir, k merupakan penulis yang memiliki jumlah dokumen paling banyak, yaitu sebanyak 16 dokumen. Dan penulis yang memiliki label paling kecil merupakan penulis yang memiliki jumlah dokumen paling sedikit, yaitu sebanyak 3 dokumen.

\section{Pembahasan}

\section{A. Komunikasi Matematis}

Komunikasi matematis memiliki peran yang penting dan harus dikuasai dalam pembelajaran, termasuk dalam pembelajaran matematika. Hal ini harus lebih ditingkatkan karena sebagian dari siswa masih rendah kemampuan komunikasi matematis. Pada zaman teknologi yang canggih saat ini siswa harus lebih berkembang teknologi dan infomasi dalam berpikir pola matematika. Menurut NCTM dalam (Suswigi et al., 2019) tujuan pembelajaran matematika, yaitu: [1] belajar untuk komunikasi, [2] belajar untuk bernalar, [3] 
belajar memecahkan masalah, [4] belajar menggunakan ide dan [5] penilaian sikap positif dalam pembelajaran matematika.

Dalam hal ini, dapat disimpulkan bahwa kemampuan komunikasi matematis tidak dapat dilepas dalam pembelajaran matematika. Komunikasi matematis jua dapat dikaitkan dengan pembelajaran matematika yang dimana pemberian materi dan cara berkomunikasi antara teman dengan guru bisa berjalan dengan baik.

Menurut Prayitno, Suwarsono, dan Siswono dalam (Nugraha \& Pujiastuti, 2019) komunikasi matematis merupakan suatu cara siswa untuk menghubungkan pengembangan ide-ide matematika kemudian menjelaskan, mendengarkan, berdiskusi, dan menyatakan lalu menyimpulkan suatu peristiwa termasuk simbol matematika yang terstruktur dan unik. Dalam proses kegiatan belajar mengajar, sangat dianjurkan mengutarakan pendapat kedalam gagasan itu, sehingga orang lain mampu untuk bertukar pikiran dalam penyampaian atau pendapat dari ide orang lain. Jadi dapat disimpulkan bahwa kemampuan komunikasi ada dua yaitu, kemampuan tulisan dan kemampuan lisan. Komunikasi lisan meliputi berdiskusi dan menjelaskan dengan menggunakan bahasa sendiri. Sedangkan komunikasi tulisan meliputi mampu mengutarakan ide matematika dalam grafik, tabel, persamaan (Rasyid, 2020). Ide-ide matematika yang banyak diberikan oleh guru juga berpengaruh terhadap kemampuan komunikasi siswa dalam pembelajaran yang ada di sekolah.

Menurut Baroody dalam (Hodiyanto, 2017) yang menjadi fokus terhadap komunikasi adalah: (1) matematika merupakan bahasa sendiri terhadap matematika, (2) kegiatan belajar mengajar matematika adalah proses sosial di sekolahan yaitu guru dan siswa. Disini ada hal komunikasi antar guru dengan siswa dalam pembelajan matematika. Saling berkomunikasi terhadap teman sebaya juga penting dan manfaatnya adalah sebagai bahan belajari untuk berpikir dalam menyelesaikan masalah matematika. Jadi pertukaran berkomunikasu dalam pembelajaran matematika akan mempengaruhi daya keterampilan komunikasi siswa tersebut. Untuk itu guru sebaiknya mengajar dengan cara penyampaian yang baru dalam proses pembelajaran yang berhubungan dengan komunikasi dengan siswa.

\section{B. Kemampuan Komunikasi Matematis Berdasarkan Gender}

Perbedaan gender adalah suatu perbedaan yang harus lebih dikaji dan disadari oleh guru, oleh sebab itu gender dapat mengakibatkan perbedaan Copyright (C) 2021

Buana Matematika :

Jurnal Ilmiah Matematika dan Pendidikan Matematika 
kemampuan komunikasi matematis yang lemah dalam pembelajaran matematika. Menurut Sosento dalam (Nugraha \& Pujiastuti, 2019) perbedaan gender tidak hanya dalam kemampuan perbedaan matematika, tetapi juga bagaimana cara memperoleh pengetahuan matematika. Pada dasarnya perbedaan gender berpengaruh terhadap sosial dan budaya pembelajaran matematika itu sendiri. Yoeanto dalam (Nugraha \& Pujiastuti, 2019) berpendapat yaitu siswa laki-laki lebih cenderung tertarik dalam mata pelajaran matematika dibanding dengan siswa perempuan, karena siswa perempuan mudah cemas, takut dan juga gugup terhadap mata pelajaran matematika.

Perbedaan gender juga dapat mempengaruhi kemampuan komunikasi matematis siswa. Oleh karena itu gender merupakan aspek yang perlu diperhatikan dalam perbedaan gender. Psikoligi perbedaan gender dalam pembelajaran matematika mempengaruhi kemampuan siswa dalam belajar, sehingga siswa laki-laki dan perempuan tidak lagi cemas, takut maupun gugup dalam menyelesaikan kemampuan matematis. Menurut Goos dalam (Ratna et al, 2019) secara universal gender adalah prestasi belajar matematika yang dikaji dengan latihan yang diberikan kepada siswa, sifat keterampilan dan pengetahuan yang diberikan latihan dan menyelesaikan tugas untuk dikerjakan oleh siswa.

Gender dalam kaitannya dengan pembelajaran komunikasi matematis merupakan area kreatifitas siswa yang banyak dan dilakukan secara tidak sadar oleh guru. Oleh karena itu guru harus memberikan tanggapantanggapan dalam berkomunikasi terhadap perbedaan gender dalam pembelajaran matematika. Maka dalam proses komunikasi dalam pembelajaran matematika guru wajib membimbing agar siswa mampu merespon secara tepat. Menurut Wood dalam (Hodiyanto, 2017) pengaruh perkembangan zaman juga bisa mempengaruhi daya kreatifitas dilihat dari gender. Disisi lain perkembangan otak siswa pada zaman sekarang juga mempengaruhi kemampuan komunikasi matematis. Hal ini dipengaruhi oleh pada siswa laki-laki lebih cenderung memakai otak kiri sehingga dapat berpikir abstrak, berpikir analitis, berpikir logis, sedangkan kemampuan siswa perempuan yang banyak digunakan adalah kapasitas otak kanannya sehingga cenderung aktif, kemudian banyak beraktifitas secara holistik, artistik, imajinatif, berpikir intuitif, dan banyak kemampuan visual yang dimilikinya. 
Dalam kemampuan komunikasi matematis siswa perempuan lebih percaya diri dibandingkan dengan siswa laki-laki. Seperti yang sudah dijelaskan bahwa gender berperan penting dalam kemampuan pembelajaran termasuk kemampuan komunikasi matematis. Oleh karena itu, meskipun adanya perbedaan gender antara kemampuan komunikasi matematis siswa laki-laki dengan perempuan, guru selaku pembimbing di sekolah, dan orang tua selaku pembimbing di rumah harus memberikan dorongan dan motivasi terhadap pembelajaran matematika yang didapat oleh siswa tersebut (Taqwa \& Sutrisno, 2019). Sehingga siswa tidak merasa berbeda dan dijauhi dalam kemampuan komunikasi matematis dalam pembelajaran matematika. Pembimbing juga harus memberikan acuan agar siswa laki-laki harus lebih fokus, karena disisi tidak ada lagi perbedaan gender terhadap kemampuan komunikasi matematis siswa terhadap pembelajaran. Maka kemampuan komunikasi matematis siswa laki-laki dan perempuan dapat ditingkatkan supaya setara, dan juga pembelajaran matemayika di sekolah dapat samasama berada tingkatan yang tinggi.

\section{Aplikasi Publish or Perish (POP)}

Publish or Perish adalah salah satu software yang digunakan untuk meninjau dan mencari sitasi akademik. Dalam hal ini informasi yang diambil dalam Publish or Perish dengan menggunakan Google scholar query yang hasilnya nanti akan dianalisis kemudian dikonversikan dalam bentuk statistik. Menurut Harzing dalam (Royani \& Idhani, 2018) hasil yang akan tampil pada pencarian tersebut dapat di save dalam format apa saja, yang diinginkan kemudian dilanjutkan dalam tahap analisis lebih dalam. Selanjutnya dalam matriks yang dihasilkan dalam software Publish or Perish ini diantaranya: total jumlah semua artikel dan jumlah sitasi. Pada sitasi dibagi menjadi sitasi ratarata per artikel, sitasi per penulis dan sitasi per tahun. Pada h-index dan gindex yang dibagi menjadi tiga variasi h-index individu dan peningkatan tahunan rata-rata h-index, kemudian yang terakhir adalah analisis jumlah penulis per artikel dan tingkat kutipan berdasarkan usia.

\section{Aplikasi VOSViewer}

VOSViewer adalah salah satu software yang digunakan untuk mengembangkan dan memvisualisasikan jaringan pada bibliometrik. Kegunaan yang dihasilkan oleh VOSViewer berupa jaringan yang mampu dalam melihat dan meliputi jurnal, peneliti atau publikasi individu. Software ini juga dapat dikembangkan lebih berdasarkan kutipan, penggabungan 
bibliografi, kutipan bersama, atau hubungan penulisan bersama. Dikutip dari (VOSviewer, n.d.), fungsionalitas dalam pengeksplorasikan teks yang mampu untuk meningkatkan lebih dalam dan memvisualisasikan jaringan yang luas dengan kejadian bersama dari istilah-istilah yang signifikan dari literaturliteratur ilmiah dapat juga dilakukan dalam aplikasi di VOSViewer ini.

\section{E. Teori Relevan}

Ada beberapa penelitian tentang bibliometrik yang dilakukan dengan metode yang mirip seperti pada penelitian yang dilakukan oleh (Aulianto et al., 2020) pada bidang kajian komunikasi untuk meninjau jurnal ilmiah dalam kemajuan ipteks dan pembangunan perkembangan keilmuan. Ada pun penelitian yang mirip juga yaitu penelitian yang dilakukan (Royani \& Idhani, 2018) yang meneliti bidang lingkungan geologi pada daerah maritim yang dilihat dari bagaimana nilai penelitian oseanografik kimia, fisik, biologi dan geologi laut.

\section{Simpulan}

Berdasarkan hasil penelitian diatas, peneliti dapat menyimpulkan bahwa dari kata kunci "Bibliometric Analysis of Mathematical Communication Skills in Mathematics Learning Based on Gender Differences using VOSViewer" ditemukan 34 kata kunci yang terbagi dalam 9 cluster. Pada jejaring kepenulisan dari 1676 penulis dengan minimal jumlah 3 dokumen yang dipulikasikan, terdapat 33 penulis yang memenuhi batas minimum jejaring kepenulisan. Kadir, k merupakan penulis yang memiliki dokumen artikel paling banyak yaitu sebanyak 16 dokumen. Publikasi terbanyak terjadi pada tahun 2020 sebanyak 306 dalam Google Scholar.

Berdasarkan simpulan diatas, peneliti dapat memberikan saran untuk penelitian selanjutnya yang dapat dimanfaatkan untuk ke depannya. Misalnya penelitian mengenai kemampuan komunikasi matematis berdasarkan jenjang pendidikan. Dalam penelitian ini hanya difokuskan pada aspek kata kunci (Co-Occurrence) dan kolaborasi penulis (Co-Authorship), sehingga memungkinkan untuk penelitia selanjutnya dapat menggunakan aspek lain, seperti sitasi, negara yang paling banyak dalam publikasi dan lainnya yang berkaitan dengan kata kunci penelusuran "Bibliometric Analysis of Mathematical Communication Skills in Mathematics Learning Based on Gender Differences using VOSViewer". 


\section{Daftar Pustaka}

Aulianto, D. R., Yusup, P. M., \& Setianti, Y. (2020). Pemanfaatan Aplikasi “ Publish Or Perish" Sebagai Alat Analisis Sitasi Pada Jurnal Kajian Komunikasi Universitas Padjadjaran. Book Chapter Seminar Nasional MACOM III "Communication and Information Beyound Boundaries, July, 873-880.

Babys, U. (2020). Analisis Kemampuan Komunikasi Matematika Siswa Ditinjau dari Gender. ANARGYA: Jurnal Ilmiah Pendidikan Matematika, 3(1), 25-29. https://doi.org/10.24176/anargya.v3i1.4771

Dari, D., \& Gender, P. (2019). 1 , 2 , 3. 2, 56-63.

Hodiyanto, H. (2017). Pengaruh Model Pembelajaran Problem Solving Terhadap Kemampuan Komunikasi Matematis Ditinjau dari Gender The Effect of Problem Solving Learning Model Toward Mathematical Communication Ability Viewed from Gender. 4(2), 219-228.

Maijala, H., Hannula, M. S., \& Pehkonen, E. (2004). Development of understanding and self-confidence in mathematics; Grades 5-8. Proceedings of the 28th Conference for the International Group for the Psychology of Mathematics Education, 3, 17-24.

Nugraha, T. H., \& Pujiastuti, H. (2019). Analisis Kemampuan Komunikasi Matematis Siswa Berdasarkan Perbedaan Gender. Edumatica: Jurnal Pendidikan Matematika, 9(1), 1-7. https://doi.org/10.22437/edumatica.v9i1.5880

Rasyid, M. A. (2020). Kemampuan Komunikasi Matematis Dalam Pembelajaran Matematika. Jurnal Edukasi: Kajian Ilmu Pendidikan, 5(1), 77-86. https://doi.org/10.51836/je.v5i1.116

Royani, Y., \& Idhani, D. (2018). Analisis Bibliometrik Jurnal Marine Research in Indonesia 1. Marine Research in Indonesia, 25(4), 63-68.

Suswigi, Septiani, U., Farhan, M. S., Purnama, T. S. A., \& Monte, I. (2019). Kemampuan Komunikasi Matematis Siswa SMP Berdasrkan Gender. Journal On Education, 1(3), 81-86. 
Taqwa, M., \& Sutrisno, A. B. (2019). Deskripsi Kemampuan Komunikasi Matematika dalam Menyelesaikan Soal Pemecahan Masalah Matematika Berdasarkan Gender. 2, 169-176.

\section{Riwayat Hidup Penulis}

\section{Dinda Haniyah}

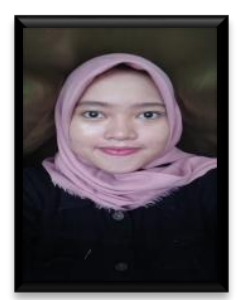

Lahir di Bekasi, 28 Februari 2000. Mahasiswi S1 di Universitas Muhammadiyah Prof. Dr. Hamka. Jakarta. Pendidikan Matematika UHAMKA.

\section{Joko Soebagyo}

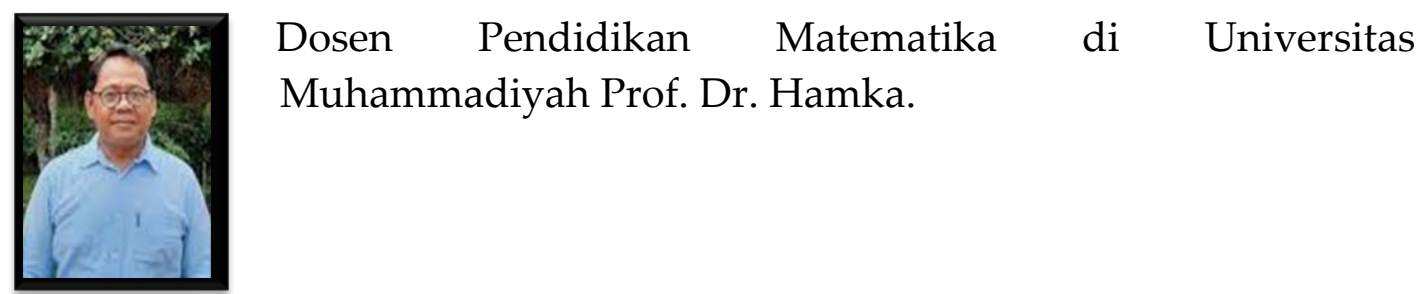

